\title{
EKSISTENSI HAK ANAK HASIL PERKAWINAN SIRI DALAM PERPEKTIF HUKUM
}

\author{
Lidya Shery Muis \\ Fakultas Hukum Universitas Airlangga \\ E-mail: lidyasherymuis@gmail.com
}

\begin{abstract}
Abstrak
Eksistensi keberadaan nikah siri yang terjadi hingga hari ini wajib mendapatkan perhatian serius, mengingat terjadi pembiaran yang di lakukan oleh Negara nantinya akan menjadi kebiasaan sehingga menjadi budaya yang tidak mendidik generasi muda. Polemic yang terjadi mengenai kekuatan putusan Perkara nomor 46/PUUVII/2010 hanya mengesahkan status dan kedudukan anak dari suatu pernikahan akan tetapi tidak memberikan tafsiran mengenai larangan atau batasan mengenai keberadaan nikah siri atau memiliki anak diluar perkawinan. Serta Eksistensi keberadaan putusan Mahkamah Konstitusi Nomor 46/PUU-VIII/2010 tentang persoalan hubungan keperdataan anak perlu di tinjau kembali menginggat Negara mengakui dan memberikan perlindungan keberadaan anak yang di buktikan dengan "asal-usul seorang anak pengakuan secara sah secara hukum merupakan langkah yang revolusioner akan tetapi pengakui sah negara terhadap anak perlu di gali kembali menginggat bagaimana mungkin Negara dapat mengakui anak dari suatu pernikahan yang tidak di lakukan secara sah menurut hukum yang berlaku, pengakui agama dari suatu pernikahan siri seyogyannya mengikat secara agama, akan tetapi yang terjadi pernikahan secara siri (agama) tetapi konsekuensinya ketika mumpunyai anak mengikat secara hukum Seyogyannya pembaruan hukum atau regulasi dilaksankan dengan berabgai pertimbangan dan permasalahan yang terjadi dengan melihat hukum progresif dan penerapan pembentukan moralitas bangsa yang terjadi hingga hari ini, maka eksistensi dari keberadaan Undang Undang No 1 Tahun 1974 tentang perkawinan sudah tidak sesuai dengan kebutuhan.
\end{abstract}

\section{Kata Kunci : Eksistensi. Anak, Perkawinan}

\begin{abstract}
The existence of the existence of unregistered marriages that has occurred to this day must receive serious attention, considering that any neglect by the State will later become a habit so that it becomes a culture that does not educate the younger generation. The polemic that occurs regarding the strength of the decision in Case number 46 / PUUVII / 2010 only validates the status and position of children from a marriage but does not provide an interpretation of the prohibitions or limitations regarding the existence of unmarried marriages or having children outside of marriage. As well as the existence of the existence of the Constitutional Court decision Number 46 / PUU-VIII / 2010 concerning the issue of child civil relations needs to be reviewed again considering that the State recognizes and provides protection for the existence of children as proven by "the legally recognized legality of a child is a revolutionary step. however, state legal recognition of children needs to be explored again considering how it is possible for the State to
\end{abstract}


recognize a child from a marriage that is not legally carried out according to applicable law, the religious confessor of a siri marriage should be religiously binding, but what happens is that marriage is unregistered. (religion) but the consequences when having children are legally binding. Law reform or regulation should be carried out with various considerations and problems that occur by looking at progressive laws and the application of the formation of national morality that has occurred to this day, then the existence of the existence of Law U ndang No. 1 of 1974 on marriage is no longer in accordance with the needs.

\section{Keywords: Existence. Son, Marriage}

\section{A. LATAR BELAKANG}

Negara Indonesia merupakan Negara yang menyatakan dirinya sebagai negara hukum (termasuk Indonesia sebagaimana Pasal 1 Ayat (3) Undang-Undang Dasar Negara Republik Indonesia Tahun 1945), sebgai Negara hukum akan melahirkan budaya hukum yang memiliki beberapa konsekuensi yang tidak dapat dihindari diantaranya; pertama; adanya penegakan hukum, kedua; perlunya jaminan mengenai independensi lembaga penegak hukum, Ketiga; kualitas produk perundang-undangan harus baik. Ketiga hal tersebut merupakan komponen penting dalam membangun negara hukum, yang didasarkan atas cita-cita bangsa (rechtsidee) ${ }^{1}$. Untuk itu Negara hadir dalam menjawab setiap permasalahan hukum yang terjadi sehingga dalam menentukan konsekuenasi, kualitas produk undang- uandang dan penegakannya sesuai dengan kebutuhan yang di harapkan. Hal ini sangat di butuhkan mengingat perlungan pengaturan regulasi yang progresif dalam mengatur interkasi sosial yang terus berkembang dewasa ini. Manusia merupakan sebagai mahkluk sosial. Sebagai mahkluk sosial manusia senantiasa akan berinteraksi dan membangun hubungan keterikatan dengan manusia lain.. antara manusia satu dengan manusia lainnya dalam hubungan perkawinan adalah untuk mendapatkan keturunan yaitu dengan cara melakukan perkawinan.. ${ }^{2}$ Perkawinan merupakan suatu ikatan yang sangat sakral dalam perjalanan kehidupan umat manusia yang ada di dunai. Dikatakan sakral karena dalam akad nikah yang dilangsungkan, pihak suami mengucapkan akad nikah dimana dia dengan suka rela telah menyatakan qabul dari ucapan ijab wali calon istri, sebab dalam Kompilasi Hukum Islam Pasal 2 disebutkan "Perkawinan menurut Hukum Islam adalah pernikahan yaitu akad yang sangat kuat atau mitsaaqan ghalizhan untuk menaati perintah Allah dan melakukannya merupakan ibadah". Perkawinan yang diharapkan menurut hukum perkawinan nasional ialah, ikatan lahir batin antara pria dan wanita sebagai suami-istri

${ }^{1}$ Sebagai suatu negara yang berdasarkan pada hukum sudah selayaknya Segala bentuk perbuatan anggota masyarakat harus berlandaskan hukum. Baik masyarakat maupun pejabat baik petani maupun menteri, siapapun nama dan pangkat harus tunduk dan patun kepada hukum. Hukumlah yang menjadi landasan seseorang untuk berbuat, di dalam koridor hukum setiap orang harus berbuat dan berperilaku baik sipil maupun militer. Sebab salah satu tujuan dari hukum adalah untuk ketertiban, kedamaian, ketentraman, dan keharmonisan dalam hubungan manusia yang satu dengan yang lainya. (Amandemen ) Undang-Undang Dasar 1945 Perubahan I sampai dengan ke IV dalam satu naskah". Merdeka Presindo, Yogyakarta 2004. Hlm. 5

2 Wati Rahmi Ria dan Muhamad Zulfikar, 2015, Ilmu Hukum Islam, Gunung Pesagi, Bandar Lampung, hlm 
dengan tujuan membentuk keluarga atau rumah tangga yang bahagia dan kekal berdasarkan Ketuhanan Yang Maha Esa. ${ }^{3}$

Prinsip dan landasan hukum perkawinan yang selama ini menjadi pegangan dan telah berlaku bagi berbagai golongan dalam masyarakat, dan bagi golongan orang-orang Islam harus diperlakukan hukum perkawinan Islam seperti yang ditetapkan oleh Undang-undang Nomor 1 Tahun 1974. Sahnya perkawinan menurut hukum Islam harus memenuhi rukunrukun dan syarat-syarat, yang mana salah satunya ialah syarat khusus bahwa kedua calon mempelai itu haruslah beragama Islam. ${ }^{4}$ Perkawinan yang sah dilegalkan oleh agama dan negara untuk membina dan membentuk sebuah keluarga yang kekal dan bahagia, namun kelalaian atau penelantaran dalam melaksanakan kewajibannya dalam keluarga, baik oleh suami maupun istri berpotensi menimbulkan retaknya hubungan rumah tangga. Putusnya suatu perkawinan akibat perceraian sebisa mungkin hanya sebagai pintu darurat yang dilakukan, jika saja perceraian menjadi jalan terakhir maka sepatutnya proses-proses perdamaian telah dilakukan baik oleh inisiatif pasangan tersebut maupun oleh usaha keluarga yang disebut "hakamain" atau juru damai maupun yang selalu diupayakan oleh hakim di Pengadilan sebelum bersidang, hendaklah upaya damai tersebut menjadi pertimbangan yang memang harus diresapi oleh pihak yang ingin bercerai. Akan tetapi tidak semua perkawianan di tata oleh Negara meskipun di sahkan oleh agama, salah satunya adalah "kawin bawah tangan", "kawin siri" atau "nikah sirri", merupakan perkawinan yang dilakukan berdasarkan aturan agama atau adat istiadat dan tidak dicatatkan di kantor pegawai pencatat nikah (KUA bagi yang beragama islam, Kantor Catatan Sipil bagi non-Islam). ${ }^{5}$ Perkawinan siri itu tidak disaksikan orang banyak dan tidak dilakukan di hadapan pegawai pencatat nikah. Hal ini tetep dianggap sesuatu yang sah sesuai dengan regulasi dalam undang- undang yang menyatakan bahwa perkawinan itu dianggap sah menurut agama meskipun tidak di catatat oleh pegawai pencatatan sipil..

Pernikahan siri yang terjadi di indonesia terjadi di Negara Indonesia memiliki banyak permasalahan dalam implementasinya hal ini dilihat dari perkampungan maupun perkotaan yang angka pernikahan siri termasuk banyak dan meningkat. Memang, masalah nikah siri ini sangat sulit untuk dipantau oleh pihak yang berwenang, karena mereka menikah tanpa sepengetahuan pihak yang berwenang tersebut. Biasanya, nikah siri dilakukan hanya dihadapan seorang ustadz atau tokoh masyarakat saja sebagai penghulu, atau dilakukan berdasarkan adat istiadat saja. Pernikahan ini kemudian tidak dilaporkan kepada pihak yang berwenang, yaitu KUA (bagi yang muslim) atau Kantor Catatan Sipil setempat (bagi yang non muslim) untuk dicatat. Melihat makin maraknya fenomena nikah siri, pemerintah berkeinginan untuk memberikan fatwa hukum yang tegas terhadap pernikahan siri. Sebagaimana penjelasan Nasaruddin Umae, Direktur Bimas Islam Depag, RUU ini akan memperketat pernikahan siri, kawin kontrak, dan poligami. ${ }^{6}$

Pernikahan siri tidak mengingkari adanya hubungan darah dan keturunan antara ayah biologis dan anak itu sendiri. Begitu juga ayah atau bapak alami tidak sah menjadi wali untuk menikahkan anaknya apabila anak tersebut perempuan hal ini membawa konsekuensi,

\footnotetext{
3 Andi Tahir Hamid, 2005, Beberapa Hal Baru Tentang Peradilan Agama dan Bidangnya, Sinar Grafika, Jakarta, hlm 9.

${ }_{4}^{4}$ Moh. Idris Ramulyo, 1999, Hukum Perkawinan Islam Suatu Analisis Dari Undang-Undang Nomor 1 Tabun 1974 dan Kompilasi Hukum Islam, Bumi Aksara, Jakarta, hlm 51.

5 Muhmud Yunus, 1979, Hukum Perkawinan Dalam Islam, Hidayakarya Agung, Jakarta, hlm 176.

${ }^{6}$ Abdulah Wasian, 2010, Akibat Hukum Perkawinan Siri (Tidak Dicatatkan) Terbadap Kedudukan Istri, Anak, dan Harta Kekayaan Tinjauan Hukum Islam dan Undang-undang Perkawinan, Universitas Dipenegoro, hlm 15.
} 
terhadap anak yang dilahirkan dari nikah siri secara hukum negara tidak mempunyai hubungan keperdataan dengan ayahnya. Hal ini memunculkan ketidakadilan kepada salah satu pihak menginggat ada pihak yang sangat di rugikan dalam hal ini. Sejalan dengan hal itu Plato berpendapat bahwa suatu perbuatan yang baik menolak undang-undang diskriminatif, dan dengan itu membela keadilan, merupakan subjek mendapatkan manfaat praktis dari itu atau tidak. Keadilan merupakan nilai yang harus dibela tanpa harus dilihat apakah pembelaan terhadap keadilan secara konkret memberi manfaat pada pembelaan atau tidak. Keadilan harus menjadi watak manusia, orang baik adalah orang yang mampu bertindak adil. Hukum yang harus ditaati demi keadilan itu bagi dalam hukum alam positif. ${ }^{7}$ Sehingga hukum yang seyogyannya harus dapat memberikan suatu gambaran terhadap suatu keadilan Hukum dibuat oleh negara untuk memenuhi rasa keadilan dan menciptakan kesejahteraan bagi warganya. Hal ini tercermin dalam pembukaan UUD 1945 menggunakan perkataan "Kesejahteraan Umum". Pertama-tama negara wajib memajukan kesejahteraan umum dengan menciptakan suatu basis kemakmuran bagi seluruh rakyat. Kemakmuran dimaksudkan ialah suatu keadaan dimana kebutuhan manusia dapat dipenuhi dengan wajar secara mantap atau terus menerus.

\section{B. METODE PENELITIAN}

Penelitian hukum dibedakan menjadi dua penelitian yuridis empiris dan yuridis normatif. Dalam penelitian yang dilakukan penulis saat ini digunakan penelitian yang yuridis normatif atau yuridis normatif " Metode penelitian ini yang digunakan oleh penulis dalam penulisan ini adalah penelitian hukum normatif, yaitu penelitian hukum doktriner, juga disebut sebagai penelitian perpustakaan atau studi dokumen. Disebut penelitian hukum doktriner, karena penelitian ini dilakukan atau ditujukan hanya pada peraturan-peraturan yang tertulis atau bahan-bahan hukum yang lain, sebagai penelitian perpustakaan atau studi dokumen disebabkan penelitian ini banyak dilakukan terhadap data yang bersifat sekunder yang ada di perpustakaan ${ }^{8}$. Sehubungan dengan tipe penelitiannya yuridis normatif maka pendekatan yang digunakan adalah pendekatan hukum yang berlaku di Indonesia (hukum positif). Suatu analisis pada hakekatnya menekankan pada metode deduktif sebagai pegangan utama, dan metode induktif sebagai tata kerja penunjang.analisis normatif mempergunakan bahan-bahan kepustakaan sebagai sumber data penelitiannya.

\section{TELAAH KONSEP}

\section{Konsep Hak}

Dalam literatur berbahasa Inggris kerap kali dikemukakan bahwa hak berdasarkan hukum (Legal Right) dibedakan dari hak yang timbul dari norma lain. Menurut Paton, hak berdasarkan hukum biasanya diartikan sebagai hak yang diakui dan dilindungi oleh hukum. Menurut Jeremy Bentham, hak adalah anak dari hukum. Dari hukum yang nyata timbul hak yang nyata. Sebaliknya dari hukum yang imajiner yaitu

${ }^{7}$ Muhammad Syukri Albani Nasution, dkk, 2016, Hukum Dalam Pendekatan Filsafat, Kencana, Jakarta, hlm .31 .

8 Bambang Waluyo, 2008, Penelitian Hukum Dalam Praktek, Jakarta, Sinar Grafika, hlm 14

9 Amirudin, Zainal Asikin, 2012, Pengantar Metode Penelitian Hukum, Jakarta, Raja Grafindo, hlm. 16 
hukum alam, timbul hak yang bersifat imajiner. Hak-hak alamiah benar-benar tidak masuk akal. Sebelum Bentham, David Hume juga berpendapat bahwa hukum alam dan hak-hak alamiah bersifat meta-fisis dan tidak nyata. Oleh karena itu Bentham berpendapat bahwa hukum yang nyata bukanlah hukum alam, melainkan hukum yang dibuat oleh lembaga legislatif ${ }^{10}$

Adapun teori kepentingan atau kemanfaatan pertama kali dijumpai dalam karya Bentham yang kemudian diadopsi oleh Rudolf von Campbell, dan lain-lain. Menurut Ihering, tujuan hukum bukanlah melindungi kehendak individu, melainkan melindungi kepentingan-kepentingan tertentu. Oleh karena itu ia mendefinisikan hak sebagai kepentingan-kepentingan yang dilindungi oleh hukum. Kepentingan-kepentingan itu bukan diciptakan oleh negara karena kepentingan itu telah ada dalam kehidupan bermasyarakat dan negara hanya memilihnya mana yang harus dilindungi ${ }^{11}$

Dalam menelaah kedua teori tersebut, Paton berpendapat bahwa esensi hak bukanlah kekuasaan yang dijamin oleh hukum, melainkan kekuasaan yang dijamin oleh hukum untuk merealisasi suatu kepentingan. Untuk menopang pendapat tersebut, Paton mengemukakan bahwa kehendak manusia tidak bekerja tanpa maksud apa-apa tetapi mengingatkan tujuan-tujuan tertentu, yaitu kepentingan. Oleh karena itu, ia menegaskan bahwa kepentingan-kepentingan adalah objek keinginan manusia. ${ }^{12}$ Hak dapat ditinjau dari beberapa segi yaitu hak orisinal hak privat, dan hak konstitusional. Menurut Prof. Jimly Asshiddiqie, Hak konstitusional merupakan hak-hak yang dijamin dalam dan oleh Undang-Undang Dasar NRI 1945. Penjaminan hak tersebut baik dinyatakan secara tegas maupun secara tersirat. ${ }^{13}$

\section{Teori keadilan}

Saint Augustine (354- 439) menyatakan bahwa "unjust law is no law at all" (Hukum yang tidak adil bukanlah hukum sama sekali) kata- kata ini menunjukkan bahwa jika suatu peraturan tidak adil maka peraturan itu bukanlah hukum ${ }^{14}$. Hukum dibuat oleh negara untuk memenuhi rasa keadilan dan menciptakan kesejahteraan bagi wargannya. Hal ini tercermin pada pembukaan Undang-Undang Dasar NRI Tahun 1945 frasa “" Kesejahteraan Umum” pertama tama negara wajib menciptakan kesejahteraan secara wajar dan mantap atau terus menerus. Keadilan pada hakekatnya merupakan perlakuan seseorang terhadap pihak lain sesuai dengan haknya. Pandangan Aristoteles tentang keadilan dalam karyannya yang berjudul nichomanchean ethics, politics dan rethiric menuangkan " hukum hanya bisa di tetapkan dalam kaitannya dengan keadilan".

\section{PEMBAHASAN}

\section{Hak anak dalam perkawinan siri dan eksistensinya}

Rawls berpendapat bahwa hak individu-individu pada posisi awal akan setuju bahwa adil untuk memiliki kesetaraan absolut untuk hak-hak dasar di antara individu-

10Peter Mahmud Marzuki, 2016, Pengantar Ilmu Hukum, Kencana, Jakarta, hlm. 142.

${ }^{11} \mathrm{G} . \mathrm{W}$ Paton, Textbook of of Jurisprudence, English language book Society, Oxford University Press, London, 1972., hlm. 151.

12Ibid., hlm. 290.

13Jimly Asshiddiqie, Konstitusi \& Konstitusionalisme Indonesia, Edisi Revisi, Konstitusi Press, Jakarta, 2005, hlm.

14J. Sondakh, Pengantar Ilmu Hukum, Manado, Universitas Sam Ratulang Pers, 2010, hlm 11.

${ }^{15}$ Carl Joachim Freindrich, Filsafat Hukum Perpektif Historis, Bandung, Nuansa, hlm 24. 
individu..16 Terjadinya Ketimpangan sosial, dalam "Prinsip perbedaan " yaitu Ketidaksetaraan pendapatan dan kesejahteraan dianggap adil jika dan hanya jika ketidaksetaraan ini untuk kepentingan yang terburuk". Langkah prinsip perbedaan ketika distribusi sumber daya keluar dari ruang lingkup prinsip pertama keadilan, seperti pendapatan dan kesejahteraan, dipertimbangkan dan tidak perlu ada kesetaraan absolut dari pendapatan dan kesejahteraan bagi masyarakat yang adil dengan ketentuan bahwa ketimpangan ini berfungsi untuk kepentingan yang paling paling merasa sangat di rugikan. ${ }^{17}$

Dalam teori keadilan, ada dua langkah menuju masyarakat yang adil dan bebas dari dikriminasi. Langkah pertama adalah musyawarah prinsip-prinsip keadilan di posisi awal, dan langkah kedua adalah mempersiapkan undang-undang untuk membentuk sistem. Rawls mengklaim bahwa pengaturan perkawinan membutuhkan pengetahuan yang kuat sehingga harus ditangani oleh orang yang memiliki keahlian itu. Karenanya undang-undang perkawianan harus disiapkan oleh para ahli dalam kerangka prinsipprinsip keadilan masyarakat yang adil dan bebas dari diskriminasi. Bergantung pada argumen ini Rawls menempatkan sesuatu yang adil dan bebas dari diskriminasi akan menghasilkan suatu hak yang tidak dapat di curangi.

Berbagai hak yang diatur dalam hak keperdataan mengenai hak anak atas pelayanan untuk mengembangkan kemampuan dan kehidupan sosialnya, sesuai dengan kepribadian bangsa untuk menjadi warga negara yang baik anak berhak atas pemeliharaan dan perlindungan baik semasa dalam kandungan maupun sesudah dilahirkan. Anak berhak atas perlindungan terhadap lingkungan hidup yang dapat membahayakan atau menghambat pertumbuhan dan perkembangan yang wajar. ${ }^{18}$ hak perwalian. Seperti diketahui bahwa dalam KUHPerdata disebutkan Perwalian itu, yaitu pada Pasal 330 ayat (3) menyatakan, "Mereka yang belum dewasa dan tidak berada di bawah kekuasaan orang tua, berada dibawah perwalian atas dasar dan cara sebagaimana teratur dalam bagian ketiga, keempat, kelima dan keenam bab ini”.

hak waris, Pengertian waris diatur dalam Pasal 833 KUHPerdata yakni pewarisan sebagai suatu proses perpindahan hak milik dari seseorang kepada orang lain atas segala barang, segala hak dan segala piutang dari seseorang yang meninggal dunia kepada para ahli warisnya. anak berhak atas pelayanan untuk mengembangkan kemampuan dan kehidupan sosialnya sesuai dengan kebudayaan dan kepribadian bangsa untuk menjadi warga negara yang baik dan berguna.

Anak berhak atas pemeliharaan dan perlindungan, baik semasa dalam kandungan maupun sesudah dilahirkan. Keenam, Anak berhak atas perlindungan terhadap lingkungan hidup yang dapat membahayakan atau menghambat pertumbuhan dan perkembangan dengan wajar. Berbicara mengenai hak waris ketentuan dalam Pasal 863

${ }^{16}$ Munson, R, 2012, Intervention and Refection Basic Issues in Bioethics. 9th. Boston: Cengage Learning, hlm.. 863

${ }^{17} J o h n$ Rawls, Fried, C, Sen, A, Schelling, TC, 1987. Liberty, Equality, and Law, 1st. Cambridge: Cambridge University Press, Hlm 18

18 Yusuf Thalib, 1984, Pengaturan Hak Anak dalam Hukum Positif, BPHN, Jakarta, hlm 132. 
KUHPerdata indonesia telah mengatur hak kewarisan anak luar perkawinan tersebut seperti berikut:

1) Mendapat $1 / 3$ (sepertiga) dari bagian mereka yang sedianya harus mendapatakannya, dari mereka yang sedianya harus mendapat, sedianya mereka adalah anak sah. Apabila pewaris meninggalkan keturunan yang sah, atau seorang suami atau istri.

2) Mendapat $1 / 2$ (seperdua) dari harta warisan, apabila pewaris tidak meningalkan keturunan maupun suami atau istri, akan tetapi meninggalkan keluarga sedarah dalam garis ke atas ataupun saudara laki-laki dan perempuan atau keturunan mereka.

3) Mendapat 3/4 (tiga perempat), apabila pewaaris hanya meninggalkan sanak saudara dalam garis derajat yang lebih jauh.

4) Mendapat seluruh harta warisan, apabila pewaris tidak meninggalkan ahli waris yang sah.

Mengurai isi dalam KUHPerdata mengenai hak waris anak luar kawin dalam KUHperdata masalah anak di luar perkawinan ini dapat mewarisi sepanjang anak tersebut telah di akui oleh kedua orang tuanya sehingga menjadi anak yang sah meskipun bagianya lebih kecil dan bebeda dengan anak sah yang sebenarnya. Berbagai regulasi yang diatur dalam berbagai regulasi KUHPerdata membutuhkan peranan kedua orang tua baik ayah maupun ibu untuk itu perlunya regulasi hukum yang jelas untuk menyelesaikan permasalahan ini, hal ini di karenakan suatu regulasi yang di buat dan disahkan seyogyannya memberikan suatu keadilan tanpa ada diskrimasi.

Eksistensi keberadaan nikah siri yang terjadi hingga hari ini wajib mendapatkan perhatian serius, jangan sampai terjadi pembiaran yang di lakukan oleh Negara yang nantinya akan menjadi kebiasaan sehingga menjadi budaya yang tidak mendidik genarasi muda. Polemic yang terjadi mengenai kekuatan putusan Perkara nomor 46/PUUVII/2010 hanya mengesahkan status dan kedudukan anak dari suatu pernikahan akan tetapi tidak memberikan tafsiran mengenai larangan atau batasan mengenai keberadaan nikah siri atau memiliki anak diluar perkawinan.

Hak Anak Dari Perkawinan Siri Menurut Pasal 43 Undang-undang Perkawinan. Berbicara mengenai hak anak dari perkawinan siri ini yang dilihat dari Pasal 43 Undangundang perkawinan dan juga Perkara nomor 46/PUUVII/2010 menjadi salah satu Putusan Mahkamah Konstitusi yang mempunyai implikasi yang sangat besar terhadap undang-undang Perkawinan khususnya yang berkaitan dengan hubungan di luar nikah tehadap ayah biologisnya, Pemohon adalah HJ. Machica dan Muhammad Iqbal Ramadhan, keduanya adalah merupakan mantan istri dan anak Moerdiono yang merupakan Mantan Menteri Sekertaris Negara pada era Orde Baru dulu. Berkaitan dengan anak yang dilahirkan diluar perkawinan, Anak luar nikah berhak mendapatkan hak-hak keperdataan dari ayah biologisnya. Karena pada posisi asli, seharusnya anak luar nikah mempunyai hak yang sama layaknya anak sah lainnya dalam memperoleh hak-hak keperdataannya. Hal tersebut adalah resiko dari perkawinan yang tidak dicatatkan atau perkawinan yang tidak dilaksanakan menurut Undang- undang perkawinan, tetapi 
tidaklah pada tempatnya jika anak harus ikut menanggung kerugian yang ditimbulkan oleh tindakan (Perkawinan) kedua orang tuanya.

Jika dianggap sebagai sanksi hukum negara maupun hukum agama (dalam hal ini agama Islam) tinggal mengenal konsep anak harus ikut menanggung sanksi akibat tindakan yang dilakukan oleh kedua orang tuannya. Dengan kata lain, potensi kerugian akibat perkawinan yang dilaksanakan untuk Pemenuhan hak-hak anak yang terlahir dari suatu perkawinan, terlepas dari sah atau tidaknya perkawinan tersebut menurut hukum negara, tetap menjadi kewajiban kedua orang tua kandung atau kedua orang tua biologisnya. Kemudian dengan keluarnya putusan Mahkamah Konstitusi (MK) yang menyatakan "anak yang dilahirkan di luar perkawinan mempunyai hubungan perdata dengan ibunya dan keluarga ibunya serta dengan laki-laki sebagai ayahnya yang dapat dibuktikan berdasarkan ilmu pengetahuan dan teknologi dan atau alat bukti lain menurut hukum mempunyai hubungan darah termasuk dengan keluarga ayahnya" yang meniadakan ketentuan Pasal 43 Undang-undang Perkawinan maka anak yang lahir dari pernikahan siri memiliki hak yang sama seperti anak sah yaitu yang pertama, hak nafkah yakni kebutuhan pokok yang diperlukan oleh orang-orang yang membutuhkannya. Mengingat banyaknya kebutuhan yang di perlukan oleh keluarga tersebut maka dari pendapat tersebut dapat dipahami bahwa kebutuhan pokok minimal adalah pangan, sedangkan kebutuhan yang lain tergantung kemampuan orang yang berkewajiban membayar atau menyediakannya dan memenuhinya, "Anak berhak atas kesejahteraan, perawatan, asuhan dan bimbingan berdasarkan kasih sayang baik dalam keluarga maupun didalam asuhan khusus untuk tumbuh dan berkembang dengan wajar".

Berdasarkan berbagai penjelasan diatas sangat jelas dapat di lihat bahwa Putusan seorang hakim dalam suatu perkara hanya hanya mengakui status dan kedudukan anak akan tetapi tidak mengatur mengenai langkah pencegahan agar tidak adanya tindakan hubungan yang nantinya dapat menimbulkan suatu keturunan. Jika suatu perkawinan siri itu sah secara agama seyognyanya sah secara hukum, sehingga setiap terjadinya perkawinan siri adanya hubungan mengikat secara perdata antara kedua belah pihak.

Penafsiran yang terjadi perkawinan siri tetap sah secara agama akan tetapi konsekuensinya mengikat secara keperdataan, sehingga penafsiran nikah sipil dan nikah resmi dianggap sama jika di lihat dari konsekuensi yang di terimannya, maka ada dualisme pengaturan yang nantinya dapat memberikan multi tafsir.

\section{Eksistensi Kedudukan Hukum Anak Perkawinan Siri}

Indonesia merupakan Negara Welfare State yang artinya tanggung jawab negara terhadap kesejahteraan warganya merupakan bagian utama dari berdirinya suatu negara. Secara sederhana dari negara kesejahteraan adalah Bentuk pemerintahan yang demokratis itu menempatkan Negara sebagai institusi itu bertanggung jawab terhadap kesejahteraan rakyat, melalui serangkaian kebijakan publik di kebijakan ekonomi dan kebijakan sosial 
untuk pencapaian kesejahteraan dan keadilan sosial di tengah masyarakat. ${ }^{19}$ Untuk itu Negara wajib menjamin hak dan kedudukan hukum sebagai bagian dari Negara hukum.

Menurut UU no 1 tahun 1974 yang mengatur mengenai sah tindaknya sutu perkawinan, dalam regulasi ini mengatur mengenai perkawinan siri atau sering di sebut nikah siri, yang secara filosofi tidak memberikan keadilan pada suatu gender tertentu hal ini tidak sejalan dengan Secara filosofi pancasila sebagai landasan suatu negara dalam kehidupan berbangsa dan bernegara. Dalam sila yang ke 5 memiliki makna dan arti filosofis. Sila Ke-5 yang berbunyi "Keadilan sosial bagi seluruh rakyat Indonesia" memiliki Lambang Padi dan kapas. Pada umumnya nilai pancasila digali oleh nilai nilai luhur nenek moyang bangsa Indonesia termasuk nilai keadilan sosial bagi seluruh rakyat indonesia. Karena digali oleh nilai nilai luhur bangsa Indonesia. pancasila mempunyai kekhasan dan kelebihan, sedangkan Prinsip keadilan yaitu berisi keharusan/ tuntutan untuk berkesesuaian dengan hakikat adil. maka manusia menyadari hak dan kewajiban yang sama untuk menciptakan keadilan sosial dalam kehidupan masyarakat Indonesia Adil dalam sila keadilan sosial ini merupakan khusus dalam artian adil terhadap manusia yang di dasari dan di jiwai oleh kebenaran terhadap diri sendiri serta adil terhadap Tuhan. Perbuatan adil menyebabkan seseorang meperoleh apa yang menjadi haknya dan dasar dari hak ini ialah pengakuan kemanusian yang mendorong perbuatan manusia itu memperlakukan sesama sebagai mestinya. Dengan demikian pelaksanaan keadilan selalu bertali dengan dengan kehidupan bersama, berhubungan dengan pihak lain dalam hidup bermasyarakat. ${ }^{20}$ Adanya hak yang di yang tidak terpenuhi dalam terjadinya perkawinana siri salah satunya adalah hak keperdataan anak dengan ayahnya sehingga segara hadir guna menjawab hal tersebut.

Negara menjamin anak atau keturunan sebagai warga negara yang dilahirkan atau dibuahkan di dalam perkawinan adalah keturunan yang sah jaminan tersebut di tuangkann dalam dan oleh undang- undang. artinya anak yang dilahirkan di dalam perkawinan tapi lahirnya setelah perkawinan orang tuanya pisah maka anak itu adalah sah. ${ }^{21}$ Keberadaan anak di luar kawin memiliki konsekuensi hukum tersendiri, sebagaimana pendapat J. Satrio yang memandang hukum perdata dalam memposisikan kedudukan anak yang dilahirkan di luar perkawinan yang sah. Seorang anak luar kawin tidak begitu saja langsung memiliki hubungan hukum kekeluargaan dengan ayah atau ibunya (orang tuanya). Anak di luar kawin memang memiliki “ kesamaan atau kemiripan” biologis dengan kedua orang tuanya, akan tetapi secara yuridis mereka tidak memiliki hak dan kewajiban apapun terhadap anak di luar kawin tersebut. Pendapat beliau dapat diartikan bahwa kedudukan seorang anak luar kawin menurut KUHPerdata tidak memiliki posisi atau ikatan apapun baik secara hukum maupun biologis, dengan kata lain anak luar kawin hidup sebatang kara di muka bumi ini, sungguh menyedihkan melihat kenyataan ini anak yang merupakan ciptaan

${ }^{19}$ Aktieva Tri Tjitrawati, The Just Drug Distribution In The Perspective Of Welfare State, Mimbar Hukum, Volume 25, Nomor 3, Oktober 2013, hlm. 2

20 Sunarjo Wreksosuharjo, 2001, Ilmu Pancasila Yuridis Kenegaraan dan Ilmu Filsafat Pancasila, Yogyakarta, Penerbit Andi, hlm 35

21 Ali Afandi, 1997, Hukum Waris Hukum Keluarga Hukum Pembuktian, PT. Reneka Cipta, Jakarta, hlm 145. 
Tuhan tidak memiliki kedudukan apapun di muka bumi ini hanya karena aturan yang dibuat oleh sesamanya. ${ }^{22}$

Berdasarkan Pasal 43 Undang-undang tentang Perkawinan menyebutkan "Anak yang dilahirkan di luar perkawinan hanya mempunyai hubungan perdata dengan ibunya dan keluarga ibunya". Pasal ini dipertegas lagi dalam Pasal 44. Seorang suami dapat menyangkal sahnya anak yang dilahirkan oleh istrinya bilamana ia dapat membuktikan bahwa istrinya telah berzina dan anak itu akibat daripada perzinahan tersebut. Pengadilan memberikan keputusan tentang sah atau tidaknya anak atas permintaan pihak yang bersangkutan. Namun dengan adanya Pasal 43 tersebut tidak akan menghilangkan hubungan anak dengan ayahnya karena bagaimanapun juga anak tersebut di lahirkan atas adanya hubungan antara seorang laki-laki dan wanita. Hal ini dinyatakan sebelum adanya perubahan pada Undang undang perkawinan. Namun dengan adanya pengajuan uji materiil yang dilakukan oleh Machica Muchtar ke Mahkamah Konstitusi, akhirnya merubah status anak luar nikah ini. Setelah menilai dan mengkaji fakta dan hukum (alasan pemohon berikut petitum permohonan dan setelah mendengar kesaksian para ahli dan keterangan dari pemerintah berikut pihak DPR-RI), maka Mahkamah Konstutusi mengabulkan permohonan para pemohon untuk sebagian. Pasal 43 ayat (1) Undangundang Nomor 16 Tahun 2019 tentang perubahan atas Undang-undang Nomor 1 Tahun 1974 tentang Perkawinan yang menyatakan, "anak yang dilahirkan di luar perkawinan hanya mempunyai hubungan perdata dengan ibunya dan keluarga ibunya", bertentangan dengan UUD 1945 sepanjang dimaknai menghilangkan hubungan perdata dengan laki-laki yang dapat dibuktikan berdasarkan ilmu pengetahuan dan tekhnologi dan atau alat bukti lain menurut hukum ternyata mempunyai hubungan darah sebagai ayahnya.

Sementara pasal 43 ayat (1) Undang-undang Nomor 16 Tahun 2019 tentang perubahan atas Undang undang Nomor 1 Tahun 1974 tentang Perkawinan yang menyatakan, "anak yang dilahirkan di luar perkawinan hanya mempunyai hubungan perdata dengan ibunya dan keluarga ibunya." Dengan demikian, pasal ini tidak memiliki kekuatan hukum mengikat sepanjang dimaknai menghilangkan hubungan perdata dengan laki-laki yang dapat dibuktikan berdasarkan ilmu pengetahuan dan tekhnologi dan atau alat bukti lain menurut hukum ternyata mempunyai hubungan darah sebagai ayahnya, sehingga ayat tersebut harus dibaca, "anak yang dilahirkan di luar perkawinan mempunyai hubungan perdata dengan ibunya dan keluarga ibunya serta dengan laki-laki sebagai ayahnya yang dapat dibuktikan berdasarkan ilmu pengetahuan dan tekhnologi dan atau alat bukti lain menurut hukum mempunyai hubungan darah, termasuk hubungan perdata dengan keluarga ayahnya.3 Dengan adanya putusan ini, tentu saja berdampak pada tatanan hukum perkawinan di Indonesia, khususnya mengenai kedudukan anak di luar perkawinan.

Kemudian Mahkamah kontsititusi meniadakan hukum tersebut dan menciptakan hukum yang baru (constitutief), "anak yang dilahirkan di luar perkawinan mempunyai

${ }^{22}$ J.Satrio, 1992, Hukum Waris, Pustaka Bangsa, Bandung, hlm 153 
hubungan perdata dengan ibunya dan keluarga ibunya serta dengan laki-laki sebagai ayahnya yang dapat dibuktikan berdasarkan ilmu pengetahuan dan teknologi dan atau alat bukti lain menurut hukum mempunyai hubungan darah, termasuk dengan keluarga ayahnya. Putusan ini bersifat declaratoir constitutief yang artinya menegaskan bahwa pasal 43 ayat (1) Undang-undang Nomor 1 Tahun 1974 bertentangan dengan UUD 1945 dan kemudian meniadakan serta menciptakan hukum baru tentang permasalahan kedudukan anak di luar perkawinan. Penciptaan hukum baru tentang permasalahan hukum kedudukan anak di luar perkawinan memberikan payung hukum terhadap anak tersebut, sehingga kewajiban orang tua, dalam hal ini adalah bapak biologisnya, akan sampai kepada pemenuhan hak-hak anak. Keadilan yang diambil majelis hakim konstitusi dalam hal ini didasarkan pada keadilan rasional, yang mana hubungan perdata antara bapak dan anak bukan hanya dapat diwujudkan melalui hubungan perkawinan namun juga melalui hubungan darah. Hukum yang terkandung dalam pasal 43 ayat (1) Undang-undang perkawinan, adalah berupaya untuk memberikan perlindungan hukum terhadap hak anak.

Selain itu juga berupaya untuk memulihkan kerugian yang timbul dari kelahiran anak di luar perkawinan. Bahwa potensi kerugian terhadap anak dalam perkawinan yang tidak didasarkan Undang-undang Nomor 1 Tahun 1974, adalah tidak ada pengakuan dari bapak biologisnya yang berhubungan dengan tidak dapat dituntutnya kewajiban bapak biologisnya untuk membiayai kebutuhan hidup anak dan hak-hak keperdataan lainya, serta kerugian sosial psikologis di tengah masyarakat yang bisa berujung pada tindakan diskriminatif.

Pengambilan hubungan darah sebagai patokan untuk adanya hubungan keperdataan antara anak luar kawin dengan bapak biologisnya, dapat melindungi hak-hak keperdataan yang dimiliki anak tersebut. Namun kerugian sosial psikologis yang diderita anak luar kawin tersebut belum tentu dapat dipulihkan. Harapan seorang anak yang dilahirkan di luar perkawinan, tentu saja adanya perubahan status dari tidak sah menjadi sah serta mempunyai kelengkapan keluarga, dalam artian mempunyai ayah kandung yang menjadi suami ibunya. Memperhatikan keserasian Pasal diatas bagaimanapun juga perkawinan tersebut harus dicatatkan demi mendapatkan kedudukan hukum yang jelas, adapula dukungan dari Putusan Mahkamah Konstitusi nomor 46/PUUVIII/2010 tentang persoalan hubungan keperdataan anak dengan ayah biologisnya, yang menyatakan pasal 43 "Anak yang dilahirkan di luar perkawinan mempunyai hubungan perdata dengan ibunya dan keluarga ibunya serta dengan laki-laki sebagai ayahnya yang dapat dibuktikan berdasarkan ilmu pengetahuan dan teknologi dan atau alat bukti lain menurut hukum mempunyai hubungan darah, termasuk hubungan perdata dengan keluarga ayahnya", karena Mahkamah Konstitusi berpendapat bahwa dalam Pasal 43 Undang-undang Perkawinan tersebut tidak memiliki kekuatan hukum mengikat sepanjang dimaknai menghilangkan hubungan perdata dengan laki-laki yang dapat dibuktikan berdasarkan ilmu pengetahuan dan teknologi serta alat bukti lain menurut hukum ternyata mempunyai hubungan darah sebagai ayahnya. 
Perkawinan siri yang menjadi bahan penelitian tersebut sah menurut agama Islam yang diyakini suami dan istri tersebut begitu juga menurut hukum setelah perkawinan tersebut di istbatkan kemudian dicatatkan, serta menurut Mahkamah Konstitusi dalam putusan nomor 46/PUU-VIII/2010 tentang persoalan hubungan keperdataan anak dengan ayah biologisnya, faktor yang menentukan sahnya perkawinan adalah syarat-syarat yang ditentukan oleh agama dari masing-masing pasangan suami istri, diwajibkannya pencatatan perkawinan oleh negara melalui peraturan perundang-undangan merupakan kewajiban administratif. ${ }^{23}$

Kemudian, setelah adanya putusan Mahkamah Konstitusi Nomor 46/PUUVIII/2010 tentang persoalan hubungan keperdataan anak dengan ayah biologisnya, akta kelahiran anak dari perkawinan siri tidak hanya mencantumkan nama ibunya tetapi dapat juga mencantumkan nama ayahnya dengan syarat penetapan dari pengadilan soal penetapan asal usul anak. Orang tua anak tersebut mengajukan permohonan penetapan pengadilan soal pengesahan anak dengan membawa alat bukti misalnya surat pernyataan pengakuan anak atau bukti melalui ilmu pengetahuan dan teknologi dan atau alat bukti lain menurut hukum yang membuktikan mempunyai hubungan darah, selanjutnya akta kelahiran dapat diterbitkan dengan mencantumkan nama ayahnya. Melengkapi Putusan Mahkamah Konstitusi ${ }^{24}$ tersebut untuk lebih akurat sebaiknya perkawinan siri tersebut di istbatkan kemudian dicatatkan melalui pencatatan sipil, dengan begitu akta kelahiran dapat di terbitkan dengan dasar akta perkawinan yang sah sesuai Pasal 55 ayat (1) UndangUndang nomor 1 tahun 1974 tentang Perkawinan menyatakan "asal-usul seorang anak hanya dapat dibuktikan dengan akta kelahiran yang autentik, yang dikeluarkan oleh pejabat yang berwenang", tentu akta kelahiran yang mencantumkan nama ibu dan ayahnya, karena tidak mungkin pula anak tersebut lahir dengan begitu saja dari rahim ibunya tetapi pasti ada peran seorang laki-laki sebagai ayahnya secara biologis, oleh karena itu dalam akta kelahiran anak tersebut harus tercantum nama ayahnya demi kejelasan asal-usul dan kedudukan status hukum anak untuk dasar mendapatkan hak sebagai anak. ${ }^{25}$

23 Putusan nomor 46/PUU-VIII/2010 tentang persoalan hubungan keperdataan anak dengan ayah biologisnya Anak dari perkawinan tersebut adalah sah, dengan demikian kedudukan hukumnya jelas sehingga mendapatkan haknya sebagai anak, selain mempunyai hubungan perdata dengan ibu dan keluarga ibunya sesuai Pasal 43 Undang-undang Perkawinan, anak tersebut juga mempunyai hubungan perdata dengan ayah dan keluarga ayahnya, karena tidak mungkin pula anak tersebut lahir dengan begitu saja dari rahim ibunya tetapi pasti ada peran seorang laki-laki sebagai ayahnya secara biologis. Atas putusan Mahkamah Konstitusi tersebut merupakan perlindungan anak dari perkawinan siri yang dilakukan oleh orang tuanya atas kedudukannya yang tidak hanya mempunyai hubungan perdata dengan ibu dan keluarga ibunya tetapi juga mempunyai hubungan perdata dengan ayah dan keluarga ayahnya

${ }^{24}$ Mahkamah Konstitusi (MK) menurut Pasal 24 ayat (1) Undang-Undang Dasar 1945 menyebutkan bahwa kekuasaan kehakiman mempunyai kekuasaan yang merdeka yang bertujuan untuk menegakkan hukum dan keadilan. Mahkamah Konstitusi sebagai salah satu lembaga peradilan yang mempunyai kekuasaan kehakiman sebagaimana disebut dalam Pasal 24C ayat (1) Undang-Undang Dasar 1945, mempunyai wewenang untuk mengadili pada tingkat pertama dan terakhir yang salah satu kewenangannya adalah menguji undang-undang terhadap Undang-Undang Dasar,

25 Eka N.A.M. Sihombing, Kedudukan Anak Luar Nikah Pasca Putusan MK Nomor 46/PUUVIII/2010, https:// sumut.kemenkumham.go.id/ berita-kanwil/ berita-utama/ kedudukan-anakluar-nikah-pasca-putusan-mknomor-46puu-viii2010. 
Problematikan yang lahir adalah putusan Mahkamah Konstitusi Nomor 46/PUUVIII/2010 tentang persoalan hubungan keperdataan anak perlu di tinjau kembali menginggat Negara mengakui dan memberikan perlindungan keberadaan anak yang di buktikan dengan "asal-usul seorang anak pengakuan secara sah secara hukum merupakan langkah yang revolusioner akan tetapi pengakui sah negara terhadap anak perlu di gali kembali menginggat bagaimana mungkin Negara dapat mengakui anak dari suatu pernikahan yang tidak di lakukan secara sah menurut hukum yang berlaku, pengakui agama dari suatu pernikahan siri seyogyannya mengikat secara agama, akan tetapi yang terjadi pernikahan secara siri (agama) tetapi konsekuensinya ketika mumpunyai anak mengikat secara hukum.

Seyogyannya regulasi atau pembaruan hukum dengan melihat hukum progresif dan penerapan pembentukan moralitas bangsa yang terjadi hingga hari ini, maka eksistensi dari keberadaan Undang Undang No 1 Tahun 1974 tentang perkawinan sudah tidak sesuai dengan kebutuhan. G.W. Paton mengemukakan bahwa Landasan paling luas dari lahirnya suatu norma hukum dan alasan bagi lahirnya suatu norma hukum ${ }^{26}$ suatu kebutuhan yang bersumber pada moralitas hukum.

\section{E. KESIMPULAN}

1. Eksistensi keberadaan nikah siri yang terjadi hingga hari ini wajib mendapatkan perhatian serius, jangan sampai terjadi pembiaran yang di lakukan oleh Negara yang nantinya akan menjadi kebiasaan sehingga menjadi budaya yang tidak mendidik genarasi muda. Polemic yang terjadi mengenai kekuatan putusan Perkara nomor 46/PUUVII/2010 hanya mengesahkan status dan kedudukan anak dari suatu pernikahan akan tetapi tidak memberikan tafsiran mengenai larangan atau batasan mengenai keberadaan nikah siri atau memiliki anak diluar perkawinan.

2. Eksistensi keberadaan putusan Mahkamah Konstitusi Nomor 46/PUU-VIII/2010 tentang persoalan hubungan keperdataan anak perlu di tinjau kembali menginggat Negara mengakui dan memberikan perlindungan keberadaan anak yang di buktikan dengan "asalusul seorang anak pengakuan secara sah secara hukum merupakan langkah yang revolusioner akan tetapi pengakui sah negara terhadap anak perlu di gali kembali menginggat bagaimana mungkin Negara dapat mengakui anak dari suatu pernikahan yang tidak di lakukan secara sah menurut hukum yang berlaku, pengakui agama dari suatu pernikahan siri seyogyannya mengikat secara agama, akan tetapi yang terjadi pernikahan secara siri (agama) tetapi konsekuensinya ketika mumpunyai anak mengikat secara hukum Seyogyannya pembaruan hukum atau regulasi dilaksankan dengan berabgai pertimbangan dan permasalahan yang terjadi dengan melihat hukum progresif dan penerapan pembentukan moralitas bangsa yang terjadi hingga hari ini, maka eksistensi dari keberadaan Undang Undang No 1 Tahun 1974 tentang perkawinan sudah tidak sesuai dengan kebutuhan.

\footnotetext{
${ }^{26}$ Agus Yudha Hernoko, Asas Proporsionalitas Dalam Kontrak Komersial, Jakarta, Kencana, hlm 13
} 


\section{DAFTAR ISI}

Amirudin, Zainal Asikin, Pengantar Metode Penelitian Hukum, Jakarta, Raja Grafindo, 2012

Agus Yudha Hernoko, Asas Proporsionalitas Dalam Kontrak Komersial, Jakarta, Kencana

Aktieva Tri Tjitrawati, The Just Drug Distribution In The Perspective Of Welfare State, Mimbar Hukum, Volume 25, Nomor 3, Oktober 2013.

Ali Afandi, 1997, Hukum Waris Hukum Keluarga Hukum Pembuktian, PT. Reneka Cipta, Jakarta.

Andi Tahir Hamid, 2005, Beberapa Hal Baru Tentang Peradilan Agama dan Bidangnya, Sinar Grafika, Jakarta

Abdulah Wasian, 2010, Akibat Hukum Perkawinan Siri (Tidak Dicatatkan) Terhadap Kedudukan Istri, Anak, dan Harta Kekayaan Tinjauan Hukum Islam dan Undang-undang Perkawinan, Universitas Dipenegoro.

Bambang Waluyo, 2008, Penelitian Hukum Dalam Praktek, Jakarta, Sinar Grafika.

Carl Joachim Freindrich, Filsafat Hukum Perpektif Historis, Bandung, Nuansa

Eka N.A.M. Sihombing, Kedudukan Anak Luar Nikah Pasca Putusan MK Nomor 46/PUUVIII/2010 , https:// sumut.kemenkumham.go.id/ berita-kanwil/ berita-utama/ kedudukan-anakluar-nikah-pasca-putusan-mk-nomor-46puu-viii2010.

Moh. Idris Ramulyo, 1999, Hukum Perkawinan Islam Suatu Analisis Dari Undang-Undang Nomor 1 Tahun 1974 dan Kompilasi Hukum Islam, Bumi Aksara, Jakarta

Muhmud Yunus, 1979, Hukum Perkawinan Dalam Islam, Hidayakarya Agung, Jakarta.

Muhammad Syukri Albani Nasution, dkk, 2016, Hukum Dalam Pendekatan Filsafat, Kencana, Jakarta.

Munson, R, 2012, Intervention and Refection Basic Issues in Bioethics. 9th. Boston: Cengage Learning.

John Rawls, Fried, C, Sen, A, Schelling, TC, 1987. Liberty, Equality, and Law, 1st. Cambridge: Cambridge University Press

J.Satrio, 1992, Hukum Waris, Pustaka Bangsa, Bandung

G.W Paton, 1972. Textbook of of Jurisprudence, English language book Society, Oxford University Press, London,

Sunarjo Wreksosuharjo, 2001, Ilmu Pancasila Yuridis Kenegaraan dan Ilmu Filsafat Pancasila, Yogyakarta, Penerbit Andi

Jimly Asshiddiqie, Konstitusi \& Konstitusionalisme Indonesia, Edisi Revisi, Konstitusi Press, Jakarta, 2005.

Munson, R, 2012, Intervention and Refection Basic Issues in Bioethics. 9th. Boston: Cengage Learning.

Yusuf Thalib, 1984, Pengaturan Hak Anak dalam Hukum Positif, BPHN , Jakarta,

Wati Rahmi Ria dan Muhamad Zulfikar, 2015, Ilmu Hukum Islam, Gunung Pesagi, Bandar Lampung. 